\title{
Characterization of the Complete Mitochondrial Genome of Ostertagia trifurcata of Small Ruminants and its Phylogenetic Associations for the Trichostrongyloidea Superfamily
}

\author{
Awais Ali Ahmad ${ }^{1}{ }^{\mathbb{D}}$, Xin Yang ${ }^{1}$, Ting Zhang ${ }^{1}$, Chunqun Wang ${ }^{1}$, Caixian Zhou ${ }^{1}$, Xingrun Yan ${ }^{1}$, \\ Mubashar Hassan ${ }^{1}$, Muhammad Ikram ${ }^{2}$ and Min $\mathrm{Hu}^{1, *}$ \\ 1 State Key Laboratory of Agricultural Microbiology, Key Laboratory for the Development of Veterinary \\ Products, Ministry of Agriculture, College of Veterinary Medicine, Huazhong Agricultural University, \\ Wuhan 430070, China; awais@webmail.hzau.edu.cn (A.A.A.); xinyang@webmail.hzau.edu.cn (X.Y.); \\ tingzhang1@webmail.hzau.edu.cn (T.Z.); wangchunqun@webmail.hzau.edu.cn (C.W.); \\ ZCX19920102@webmail.hzau.edu.cn (C.Z.); yanxingrun@webmail.hzau.edu.cn (X.Y.); \\ mubashar.hassan@webmail.hzau.edu.cn (M.H.) \\ 2 Statistical Genomics Lab, College of Plant Science and Technology, Huazhong Agricultural University, \\ Wuhan 430070, China; ikramuaf35@outlook.com \\ * Correspondence: mhu@mail.hzau.edu.cn
}

Received: 3 January 2019; Accepted: 29 January 2019; Published: 31 January 2019

\begin{abstract}
The complete mitochondrial (mt) genome of Ostertagia trifurcata, a parasitic nematode of small ruminants, has been sequenced and its phylogenetic relationship with selected members from the superfamily Trichostrongyloidea was investigated on the basis of deduced datasets of $\mathrm{mt}$ amino acid sequences. The entire mt genome of Ostertagia trifurcata is circular and 14,151 bp in length. It consists of a total of 36 genes comprising 12 genes coding for proteins (PCGs), 2 genes for ribosomal RNA (rRNA), 22 transfer RNA (tRNA) genes and 2 non-coding regions, since all genes are transcribed in the same direction. The phylogenetic analysis based on the concatenated datasets of predicted amino acid sequences of the 12 protein coding genes supported monophylies of the Haemonchidae, Dictyocaulidae and Molineidae families, but rejected monophylies of the Trichostrongylidae family. The complete characterization and provision of the mtDNA sequence of Ostertagia trifurcata provides novel genetic markers for molecular epidemiological investigations, systematics, diagnostics and population genetics of Ostertagia trifurcata and its correspondents.
\end{abstract}

Keywords: Ostertagia trifurcata; mitochondrial genome; mitochondrial DNA; phylogenetic analysis

\section{Introduction}

Gastrointestinal parasites cause major economic losses to the livestock industry all over the world [1]. Among these parasites, Ostertagia spp., which is a reddish brown worm present in the abomasum of ruminants, is a major cause of parasitic gastritis (ostertagiosis) worldwide, particularly in temperate climates. Ostertagia spp. is considered to be among the most common gastrointestinal nematodes of ruminants [2]. Postmortem examination of small ruminants revealed a high infection rate in goats in China [2]. More than 15 Ostertagia species have been reported in small ruminants [3-5]. Among them, Ostertagia trifurcata (O. trifurcata) is distributed widely and has a lifecycle similar to Haemonchus contortus, another important parasitic nematode of small ruminants. Animals infected with Ostertagia spp. show the presence of eggs in fecal samples 15-17 days after infection [6]. Importantly, Ostertagia spp. is prevalent in both temperate and cold climates [7]. Heavy infection leads 
to emaciation, anemia, intermittent constipation and even death in extreme cases [8]. In China, it is one of the most predominant nematodes of ruminants and contributes to substantial financial losses [9].

Mitochondria are a subcellular organelle with important biochemical functions. This organelle is the powerhouse of the eukaryotic cell. The mitochondrial (mt) genome is located within the organelle, independent of the nuclear genome but with a closer relationship to each other. The mt genome is maternally inherited, and has stable genes, a variable gene arrangement and a faster gene evolution rate [10-12]. These features make them widely applicable in epidemiological studies, population genetics and phylogenetic relationships at different taxonomic levels [13-17].

The current hypothesis of Trichostrongylidae's phylogeny was based on ecological and morphological characteristics along with the sequence analysis of small subunit (SSU) rRNA genes [6,18]. Moreover, reconstructions of phylogenetic relationships among Trichostrongylidae nematodes have been performed using the mt genome sequences [19]. Regardless of the advancements, there is still ambiguity relating to the phylogenetic relationships among Trichostrongylidae nematodes. Some previous studies were indicative of Trichostrongylidae monophyly [20,21], whereas other studies support a contrary argument and are suggestive of a sister relationship among Trichostrongylidae, Haemonchidae and Cooperiidae [18,22,23]. Insufficient perseverance at higher levels of taxonomy with dissimilar datasets of DNA, as well as the utilization of distinct methods for inference may result in such inconsistent results. Even though Trichostrongylidae is a large family of nematodes, the number of complete mt genomes sequenced to date are limited [19]. The enrichment of information on the mt genome of helminths, especially those infecting small ruminants, is required to augment database and species characterization, which provides valuable information for future studies on the identification of species, phylogenetic analysis and genetic diversity. There is very limited availability of genomic data on the mt genome of members of Ostertagia genus. This lack of adequate knowledge about the mt genomes of nematodes is a key limitation for studies of the phylogenetic relationship of Trichostrongylidae.

Keeping in view the background and connotation of O. trifurcata, the current study intended to determine the $\mathrm{mt}$ genome composition of $O$. trifurcata and a reconstruction of the phylogenetic relationship of the Trichostrongyloidea superfamily using these mtDNA sequences.

\section{Materials and Methods}

\subsection{Collection of Worms and Extraction of DNA}

The adult worms from the abomasum of naturally-infected domesticated sheep and goats in Luotian, Hubei, P.R. China were collected. The collected worms were subsequently washed in $0.9 \%$ sodium chloride solution and identified as Ostertagia based on their morphological characteristics. Samples were then washed with phosphate buffered saline (PBS), fixed in 70\% ethyl alcohol, and stored at $-20{ }^{\circ} \mathrm{C}$ until next use. It was challenging to attain precise morphological characteristics of, so molecular identification was carried out. For the extraction of the total genomic DNA from single worm Ostertagia samples, Sodium dodecyl (SDS)-proteinase K treatment was performed, trailed by purification using mini column (Wizard®SV Genomic DNA Purification System, Promega).

\subsection{Amplification of the ITS-2 of Ostertagia trifurcata}

To identify the organism, the ITS-2 region was amplified and then sequenced according to a previously described method [24]. The universal primers NC5 and NC2 (Table 1) were used for the amplification of the ITS-2 region. A total volume of $20 \mu \mathrm{L}$ was prepared including DNA template, primers and PCR premix (Takara, Dalian, China). The conditions used for PCR amplification were initially $94{ }^{\circ} \mathrm{C}$ for 5 min followed by 35 cycles of $94{ }^{\circ} \mathrm{C}$ for 30 seconds, $50{ }^{\circ} \mathrm{C}$ for 30 seconds and $72{ }^{\circ} \mathrm{C}$ for $1 \mathrm{~min}$, final extension at $72{ }^{\circ} \mathrm{C}$ for $10 \mathrm{~min}$, and the reaction was stopped at $20{ }^{\circ} \mathrm{C}$ for $5 \mathrm{~min}$. 
Table 1. Sequences of primers used to amplify ITS-2 region and long fragments of mitochondrial DNA from Ostertagia trifurcata.

\begin{tabular}{lll}
\hline Primer & \multicolumn{1}{c}{ Sequence $\left(\mathbf{5}^{\prime}\right.$ to $\mathbf{3}^{\prime} \mathbf{)}$} & Region \\
\hline NC5 & GTAGGTGAACCTGCGGAAGGAT & ITS-2 \\
NC2 & TTAGTTTCTTTTCCTCCGCT & \\
$37 \mathrm{~F}$ & GGAGTAAAGTTGTATTTAAAC & \\
$36 \mathrm{R}$ & CCTCAAACTAAAACATAACC & \\
$45 \mathrm{~F}$ & ACTAGTTTGTTAAGTGTTATTCCT & cytb-ox1 \\
$48 \mathrm{R}$ & ATAAACCTCAGGATGCCCAAAAAA & \\
CO1F & TTTTTTGGGCATCCTGAGGTTTAT & cox1-rrnL \\
$40 \mathrm{R}$ & GAATTAAACTAATATCACGT & \\
$39 \mathrm{~F}$ & TAAATGGCAGTCTTAGCGTGA & rrnL-rrnS \\
$4 \mathrm{R}$ & TCTACTTTACTACAACTTACTCC & \\
\hline
\end{tabular}

\subsection{Amplification of Long Fragments and Sequencing}

The primers used in amplifying long overlapping fragments of mitochondrial genome were relative to their conserved regions (Table 1) [25]. Long-range PCR was used to amplify the whole $\mathrm{mt}$ genome of $O$. trifurcata in four overlapping fragments with locations of amplicons between $r r n S$ and cytb $(\sim 3 \mathrm{~kb}), c y t \mathrm{~b}$ and $c o x 1(\sim 4 \mathrm{~kb}), c o x 1$ and $r r n \mathrm{~L}(\sim 3 \mathrm{~kb})$ and $r r n \mathrm{~L}$ and $r r n S(\sim 5 \mathrm{~kb})$. The long PCRs were performed by making a total volume of $50 \mu$ l per amplicon, with the reaction mixture containing $34.75 \mu \mathrm{L} \mathrm{dH}{ }^{2} \mathrm{O}, 5 \mu \mathrm{L}$ of $10 \times$ Thermopol reaction buffer (Biolabs, New England), $10 \mathrm{mM}$ of each dNTP (Takara, Dalian, China), 1.25U LATaq (Takara, Dalian, China), $2 \mu \mathrm{M}$ of each primers (TsingKe, Beijing, China) and $2 \mu \mathrm{L}$ of genomic DNA in a thermocycler (Biometra, Göttingen, Germany). The PCR conditions for the amplification were initiated by denaturation at $94{ }^{\circ} \mathrm{C}$ for $5 \mathrm{~min}$, followed by 35 cycles of denaturation for 30 seconds at $94^{\circ} \mathrm{C}$, annealing for 30 seconds at $50{ }^{\circ} \mathrm{C}$, extension for $5 \mathrm{~min}$ at $60^{\circ} \mathrm{C}$, with $7 \mathrm{~min}$ of final extension at $60{ }^{\circ} \mathrm{C}$, and finally the reaction was stopped at $4{ }^{\circ} \mathrm{C}$. The obtained amplicons were then cloned into pGEM-T-Easy vector (Promega, USA), which were sequenced (Sangon BioTech company, Shanghai, China) employing a strategy of primer-walking [26]. The complete mitochondrial genome of O. trifurcata (GenBank accession no. MK227249) was thus obtained.

\subsection{Gene Annotation and Sequence Analysis}

The mt genome annotation was performed by implementing a methodology similar to Ascaridomorph nematodes [27]. The assembly of sequences was carried out manually and the assembled sequences were subsequently aligned against the entire $\mathrm{mt}$ genome sequences of the reference species (Teladorsagia circumcincta, accession number GQ888720) to identify gene boundaries. The Open Reading Frame Finder (<http:/ / www.ncbi.nlm.nih.gov/gorf/gorf.html>) and DOGMA tool (http:/ / dogma.ccbb.utexas.edu/index.html) were used to analyze the open reading frames using the invertebrate mitochondrial code with further comparison performed using other enoplid nematodes. The MEGA5 software was used to select the invertebrate $\mathrm{mt}$ genetic code for the translation of individual genes into amino acid sequences. The amino acid sequences of other nematodes were then aligned with the resulting sequences of amino acids inferred for the $\mathrm{mt}$ genes using Clustal $\times$ 1.83. Based on the pairwise comparison, amino acid identity (\%) was also calculated for homologous genes. Codon usage was inspected whereby the genetic codons were split into rich GC codons, rich AT codons and neutral codons based on the relationships among codon families, the occurrence of amino acids and composition of nucleotides. To examine the rRNA genes, presumed secondary structures of tRNA genes were recognized using ARWEN (http:/ / mbio-serv2.mbioekol.lu.se/ARWEN/) [28,29] as well as visual inspection [30].

\subsection{Phylogenetic Analysis on Basis of the Dataset of Amino Acid Sequences}

Individual genes of the $O$. trifurcata $\mathrm{mt}$ genome were translated to obtain amino acid sequences that were then integrated to form a single alignment. These sequences were aligned with other 
deduced sequences of amino acids from already-published $\mathrm{mt}$ genomes. Selective nematodes were representatives for comparison with the superfamily Trichostrongyloidea, featuring family Trichostrongylidae (Trichostrongylus vitrinus, NC_013807; Trichostrongylus axei, NC_013824; Teladorsagia circumcincta, NC_013827; Marshallagia marshalli, MG011723) [19,31], Molineidae family (Nematodirus oiratianus, NC_024639, and Nematodirus spathiger, NC_024638) [22], Cooperiidae family (Cooperia oncophora, NC_004806) [32], Haemonchidae family (Mecistocirrus digitatus, NC_013848, Haemonchus placei, NC_029736) [19] and (Haemonchus contortus, NC_010383) [33], Dictyocaulidae family (Dictyocaulus eckerti, NC_019809; Dictyocaulus viviparus, NC_019810;) [34], whereas Oesophagostomum quadrispinulatum (GenBank accession number NC_014181) [23] was selected as an outgroup. The individual sequential alignment of amino acids derived from $\mathrm{mt}$ protein coding genes was performed using the MAFFT 7.122 software [35] and were chained into a single dataset. Furthermore, sequences that were aligned ambiguously were removed according to a previously described method [31]. Phylogenetic assessment was piloted using the neighbor joining (NJ), maximum likelihood (ML) and maximum parsimony (MP) methods using default parameters according to a formerly described method [36,37]. The bootstrap values for NJ and MP were 1000, whereas bootstrap 100 was selected for the ML analysis with a cutoff value of $95 \%$ for all methods. The number of differences model was used by NJ to infer the phylogenetic tree, and in the case of ML the uniform rates model was used. MP used the subtree-pruning-regrafting search method where the maximum trees to retain were 100. The FigTree v. 1.4 program (http:/ / tree.bio.ed.ac.uk/software/figtree) was used to construct the phylograms.

\section{Results and Discussion}

\subsection{ITS-2 Analysis}

The obtained ITS-2 sequence had 99\% identity to a previously published ITS-2 sequence of $O$. trifurcata (GenBank Accession no. AJ251124.1), suggesting that the worms collected are Ostertagia trifurcata.

\subsection{Organization, Content and $m$ t Genome Annotation}

The complete mt genome of O. trifurcata (GenBank accession no. MK227249) was 14,151 bp in length (Figure 1). The mt genomes of Trichostrongyloidea published to date possess variations in size that range from 13,296 bp of Dictyocallus eckerti [34] to 15,221 bp of Mecistocircus digitatus [19]. The size of the O. trifurcata $\mathrm{mt}$ genome was found to be within the expected range, i.e., 14,151 bp. This mt genome includes 12 protein-coding genes (nad1-6, cox1-3, cytb, nad4L and atp6), 2 rRNA genes, 22 tRNA genes and 2 non-coding regions (NC) (Table 2). The nucleotide composition of the coding strand of $O$. trifurcata was $\mathrm{A}=4639(32.78 \%), \mathrm{T}=6418(45.35 \%), \mathrm{G}=2106(14.88 \%)$ and $\mathrm{C}=988(6.98 \%)$. The gene contents and their organization were the same as those of M. marshalli [31], D. viviparus [34], N. oiratianus [22], T. axei [19] and H. contortus [33]. 


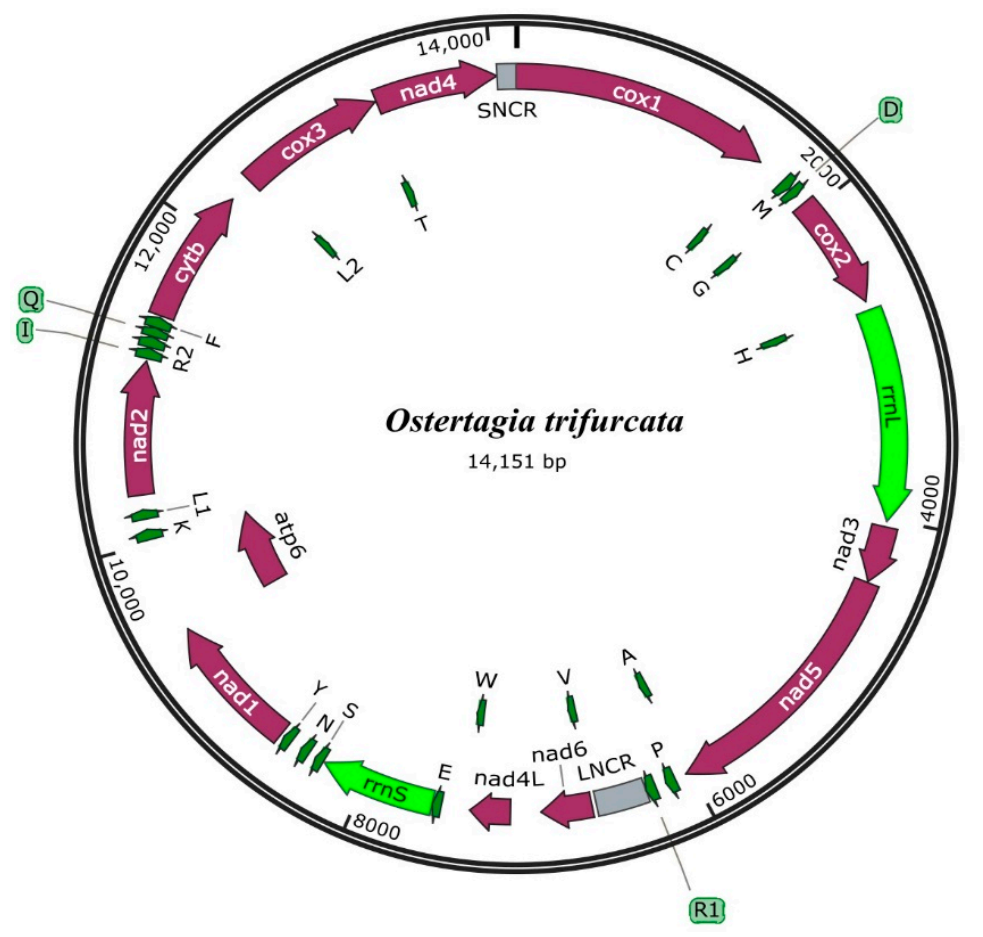

Figure 1. Mitochondrial genome arrangement of Ostertagia trifurcata. The scales are similar and all the genes are transcribed in the clockwise direction. The genes follow the standard nomenclature, except for the 22 tRNA genes, which are designated using one-letter amino acid codes with numerals differentiating each of the two leucine and arginine-specifying tRNAs (L1 and L2 for codon families UUR and CUN, respectively; R1 and R2 for codon families AGR and CGN, respectively). The tRNA genes and atp 6 located on the inner circle indicate regions of gene overlap.

The mt genome of $O$. trifurcata encodes 12 proteins with 3181 amino acids. It accords three start codons (ATA, ATT, ATG) and two termination codons (TAA, TAG) (Table 2). Amongst the initiation codons, ATT was more frequently used, namely eight times by cox1, cox2, nad5, nad6, nad1, atp6, nad 2 and nad4. ATA was utilized three times as the start codon by the nad 3 , cytb and cox 3 genes, whereas ATG was used once as the start codon for the nad4L gene. In the case of stop codons, TAA was most frequently used as the stop codon, namely ten times by the cox $1, \operatorname{cox} 2$, cox3, nad5, nad6, nad $4 \mathrm{~L}, n a d 1$, atp6, nad 2 and cytb genes. The other stop codon was TAG, which was used by the nad 3 and nad 4 genes. These results are consistent with other studies of Trichostongyloidea nematodes (T. circumcincta, T. axei and T. vitrinus) [19], with some marked differences. In some previous mt genome studies of other nematodes of Trichostrongyloidea (T. vitrines, T. axei and T. circumcincta) [19], four start codons (ATA and TTG) were found, as well as incomplete stop codons (TA and A). However, in the present study, ATT and ATA were used as the initiation codons in the higher frequency by eleven protein coding genes and ATG was used once as a start codon. The present study also revealed the usage of complete termination codons as the stop codon. TAA was used altogether 10 times as the termination codon, and our data suggests the use of complete stop codons for all 12 genes coding for proteins. O. trifurcata is markedly different from other nematodes with regard to the basis of the start and stop codons, hence the provision of new molecular data provides insights into future studies of comparative mitochondrial genomics. Furthermore, the O. trifurcata $\mathrm{mt}$ genome possesses several overlaps between the CDS region and trnAs (Table 2). One nucleotide of $\operatorname{cox} 1$, cox2 and nad4 overlaps with $\operatorname{trn} \mathrm{C}$, $\operatorname{trn\mathrm {H}}$ and $\operatorname{trn} \mathrm{T}$, respectively, whereas the nad1-atp6 and $\operatorname{trn} \mathrm{G}-\operatorname{cox} 2$ genes had overlaps of four and nine nucleotides, respectively. Moreover, there were longer overlaps in the $\mathrm{mt}$ genome sequence ranging from 20-50 nucleotides between nad4L-trnW, atp6-trnK, $\operatorname{trn} \mathrm{V}-n a d 6, \operatorname{cox} 3-\operatorname{trn} \mathrm{T}, n a d 5-\operatorname{trn} \mathrm{A}$, and $\operatorname{tr} \mathrm{L} 2$ overlapping with the $\operatorname{cox} 3$ gene. 
Table 2. Structure of the mitochondrial genome of Ostertagia trifurcata and nucleotide positions of the starting and termination sites as well as the length of each gene and the number of encoded amino acids, starting and terminator codons of protein coding genes and anticodons for tRNAs starting from $\operatorname{trn} \mathrm{C}$.

\begin{tabular}{|c|c|c|c|c|}
\hline Gene/codons & Position and sequence length of $\mathrm{nt}$ & Amino acids & Start/stop codons & Anticodons \\
\hline $\operatorname{cox} 1$ & $1-1578(1578)$ & 525 & ATT/TAA & \\
\hline $\operatorname{trn} \mathrm{C}$ & $1578-1634(57)$ & & & GCA \\
\hline $\operatorname{trn} \mathrm{M}$ & $1753-1813(61)$ & & & CAT \\
\hline $\operatorname{trn} \mathrm{D}$ & $1823-1876(54)$ & & & GTC \\
\hline $\operatorname{trn} \mathrm{G}$ & $1893-1948(56)$ & & & TCC \\
\hline $\cos 2$ & $1937-2644(708)$ & 235 & ATT/TAA & \\
\hline $\operatorname{trn} \mathrm{H}$ & $2644-2699(56)$ & & & GTG \\
\hline$r r n \mathrm{~L}$ & $2700-4014(1315)$ & & & \\
\hline nad3 & $4048-4398(351)$ & 116 & ATA/TAG & \\
\hline nad5 & $4405-6030(1626)$ & 541 & ATT/TAA & \\
\hline $\operatorname{trn} \mathrm{A}$ & $5986-6044(59)$ & & & TGC \\
\hline $\operatorname{trn} \mathrm{P}$ & $6102-6162(61)$ & & & TGG \\
\hline $\operatorname{trn} \mathrm{R}_{1}(\mathrm{AGR})$ & $6227-6288(62)$ & & & TCT \\
\hline LNCR & $6289-6596(308)$ & & & \\
\hline $\operatorname{trn} \mathrm{V}$ & $6597-6653(57)$ & & & TAC \\
\hline nad6 & $6623-6928(306)$ & 101 & ATT/TAA & \\
\hline $\operatorname{nad} 4 \mathrm{~L}$ & $7110-7352$ (243) & 80 & ATG/TAA & \\
\hline $\operatorname{trn} \mathrm{W}$ & $7332-7389$ (58) & & & TCA \\
\hline $\operatorname{trn} \mathrm{E}$ & $7523-7577$ (55) & & & TTC \\
\hline$r r n S$ & $7578-8270$ (693) & & & \\
\hline $\operatorname{trn} \mathrm{S}$ & $8277-8330(54)$ & & & TGA \\
\hline $\operatorname{trn} \mathrm{N}$ & $8376-8431(56)$ & & & GTT \\
\hline $\operatorname{trn} \mathrm{Y}$ & $8502-8556$ (55) & & & GTA \\
\hline nad 1 & 8578-9432 (855) & 284 & ATT/TAA & \\
\hline atp6 & $9428-10045$ (618) & 205 & ATT/TAA & \\
\hline $\operatorname{trn} \mathrm{K}$ & $10025-10088(64)$ & & & TTT \\
\hline $\operatorname{trn} \mathrm{L}_{1}$ (UUR) & $10153-10210(58)$ & & & TAA \\
\hline $\operatorname{nad2}$ & $10302-11126(825)$ & 274 & ATT/TAA & \\
\hline $\operatorname{trn} \mathrm{I}$ & $11141-11205$ (65) & & & GAT \\
\hline $\operatorname{trn} \mathrm{R}_{2}(\mathrm{CGN})$ & $11211-11277$ (67) & & & ACG \\
\hline $\operatorname{trn} \mathrm{Q}$ & $11280-11336$ (57) & & & TTG \\
\hline $\operatorname{trn} \mathrm{F}$ & $11337-11403$ (67) & & & GAA \\
\hline$c y t b$ & 11415-12251 (837) & 278 & ATA/TAA & \\
\hline $\operatorname{trn} \mathrm{L}_{2}(\mathrm{CUN})$ & $12435-12490(56)$ & & & TAG \\
\hline $\cos 3$ & $12401-13294(894)$ & 297 & ATA/TAA & \\
\hline $\operatorname{trnT}$ & 13244-13301 (58) & & & TGT \\
\hline nad4 & $13301-14038$ (738) & 245 & ATT/TAG & \\
\hline SNCR & 14039-14151 (113) & & & \\
\hline
\end{tabular}

The $O$. trifurcata $\mathrm{mt}$ genome has 22 tRNA genes that range between 54 and 67 nucleotides in length. The $r r n \mathrm{~L}$ gene of $O$. trifurcata is positioned between the $t r n \mathrm{H}$ and nad 3 genes with a length of $1315 \mathrm{bp}$. The $r r n \mathrm{~S}$ gene is situated between the two tRNA genes represented as $\operatorname{trn} \mathrm{E}$ and $t r n \mathrm{~S}$. The A+T content of both the rRNA genes is high, at $81.66 \%$ and $77.63 \%$, respectively, for $r r n \mathrm{~L}$ and $r r n \mathrm{~S}$ (Table 3 ). The $\mathrm{mt}$ genome of $O$. trifurcata possesses two non-coding regions, represented as LNCR (large non-coding region) and SNCR (short non-coding region) (Table 2). The longer non-coding region (LNCR) is sited between the trnR1 gene and $t r n \mathrm{~V}$ with a length of $308 \mathrm{bp}$, whereas the shorter non-coding region (SNCR) is positioned between the nad4 and cox 1 gene, with a length of $113 \mathrm{bp}$ (Table 2). The A+T contents was found to be higher for both non-coding regions, at $80.19 \%$ and $76.10 \%$ for LNCR and SNCR, respectively. These non-coding regions might play a vital role in replication and transcription processes, however, the authentic processes are still unknown [38]. 
Table 3. Composition of nucleotides and skew values of Ostertagia trifurcata mitochondrial protein-coding genes.

\begin{tabular}{llllllll}
\hline Gene & A & G & C & T & A+T (\%) & AT skew & GC skew \\
\hline cox1 & 25.98 & 20.08 & 10.89 & 43.02 & 69.00 & -0.24 & -0.29 \\
cox2 & 31.35 & 17.37 & 8.61 & 42.65 & 74.00 & -0.15 & -0.33 \\
nad3 & 33.33 & 13.96 & 3.70 & 49.00 & 82.33 & -0.19 & -0.58 \\
nad5 & 31.54 & 13.71 & 6.39 & 48.33 & 79.87 & -0.21 & -0.36 \\
nad6 & 27.12 & 14.05 & 4.90 & 53.92 & 81.04 & -0.33 & -0.48 \\
nad4L & 32.09 & 16.87 & 2.46 & 48.55 & 80.64 & -0.20 & -0.74 \\
nad1 & 25.84 & 17.66 & 7.95 & 48.53 & 74.37 & -0.30 & -0.37 \\
atp6 & 28.96 & 17.31 & 6.14 & 47.57 & 76.53 & -0.24 & -0.47 \\
nad2 & 30.42 & 11.63 & 5.21 & 52.72 & 83.14 & -0.26 & -0.38 \\
cytb & 27.83 & 18.87 & 9.67 & 43.84 & 71.67 & -0.22 & -0.32 \\
cox3 & 28.63 & 16.55 & 7.60 & 47.20 & 75.83 & -0.24 & -0.37 \\
nad4 & 29.13 & 13.41 & 7.04 & 50.40 & 79.53 & -0.26 & -0.31 \\
rrnL & 37.79 & 12.24 & 6.08 & 43.87 & 81.66 & -0.07 & -0.33 \\
rrnS & 36.65 & 14.71 & 7.64 & 40.98 & 77.63 & -0.05 & -0.31 \\
LNCR & 37.66 & 16.88 & 2.92 & 42.53 & 80.19 & -0.06 & -0.70 \\
SNCR & 32.74 & 10.61 & 13.27 & 43.36 & 76.10 & -0.13 & -0.11 \\
Overall & 32.78 & 14.88 & 6.98 & 45.35 & 78.13 & -0.16 & -0.36 \\
\hline
\end{tabular}

\subsection{Phylogenetic Analysis}

The sequences of amino acids of the 12 key representative nematodes belonging to the Trichostrongyloidea superfamily were concatenated to infer the phylogenetic tree (Figure 2) producing similar results using the maximum parsimony (MP), maximum likelihood (ML) and neighbor joining (NJ) methods. The results showed monophylies of Molineidae, Dictyocaulidae and Haemonchidae with significant statistical support, as shown in Figure 2. However, monophyly of the family Trichostrongylidae was rejected and these results were consistent with preceding studies $[18,22,23]$. Haemonchidae family species ( $M$. digitatus, $H$. contortus and H. placei) were found to be more closely linked to the two species of the Trichstongylidae family compared to the other three species (O. trifurcata, Teladorsagia circumcincta and Marshallagia marshalli) belonging to the same family. The closer relationship within the Haemonchidae family was supported moderately (bootstrap values of NJ/ML/MP: 95/93/62, respectively) (Figure 2). Molineidae family species (N. oiratianus and N. spathiger) were found to be closer in evolutionary relationship to Dictyocaulidae family species $(D$. viviparous and $D$. eckerti) compared to Trichostrongylus spp., (O. trifurcata, T. circumcincta) and Cooperidae (C. oncophora). The results in our study were consistent with earlier studies [22,31]. 


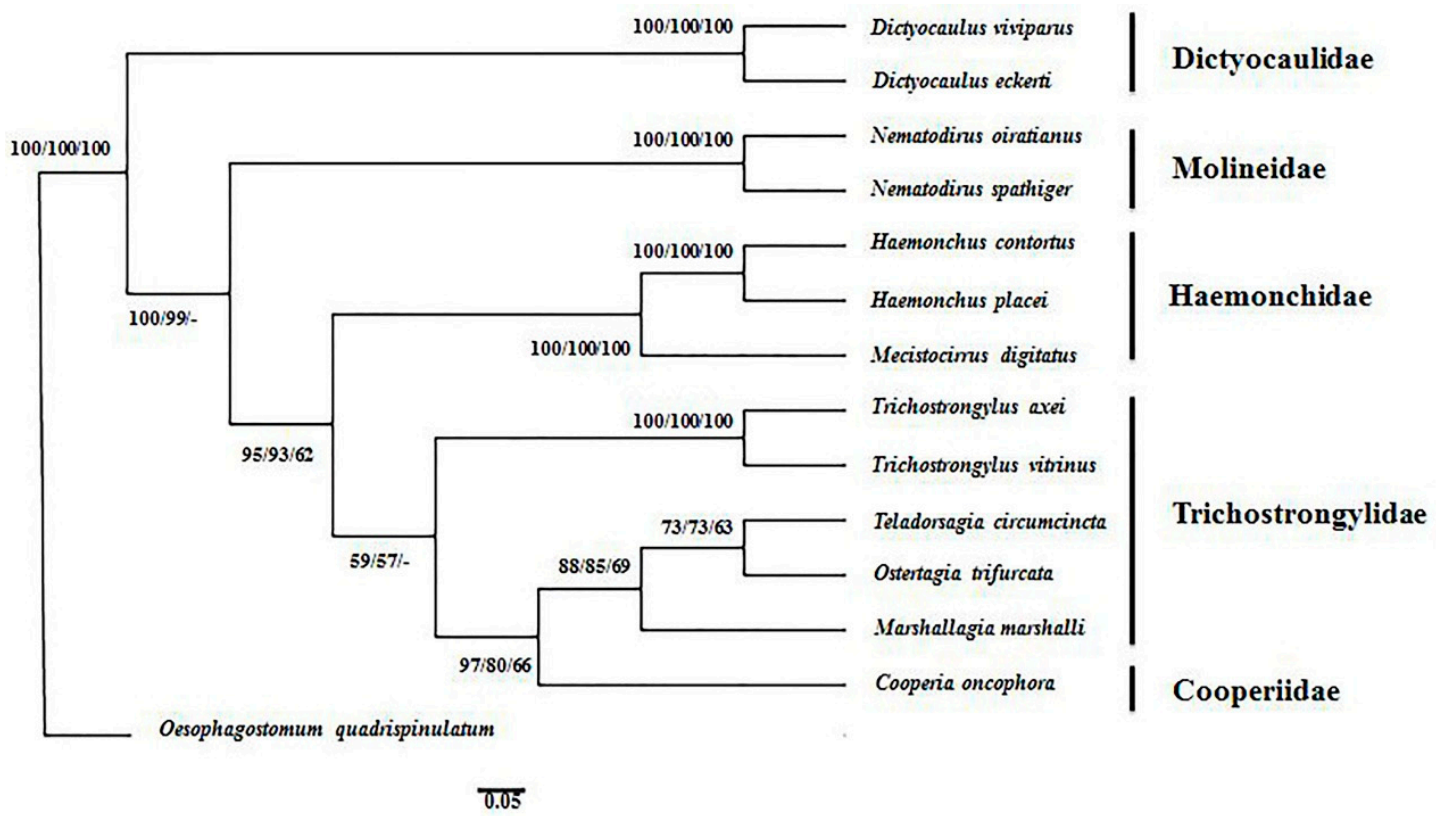

Figure 2. Phylogenetic tree inferred from concatenated amino acid sequences of 12 protein coding genes of key parasitic nematodes belonging to the Trichostrongyloidea family. Phylogenetic relationships of Ostertagia trifurcata and other members of Trichostrongyloidea were inferred using the neighbor joining (NJ), maximum likelihood (ML) and maximum parsimony (MP) methods. Oesophagostomum quadrispinulatum (GenBank accession number NC_014181) was chosen as the outgroup. The numbers along the branches indicate bootstrap values resulting from the analysis using NJ/ML/MP, where the values under 50 are given as "-".

\section{Implications and Significance}

Gastrointestinal nematodes causing animal infections including ostertagiosis can sometimes be diagnosed on the basis of clinical presentation and symptoms such as chronic diarrhea, depressed appetite and high morbidity [1]. However, diagnosis only on the basis of clinical symptoms is usually unreliable as these symptoms can be present in animals with one or more gastrointestinal nematode members. The morphological identification of $O$. trifurcata is also not reliable enough at the larval stages. Fortunately, numerous DNA scientific methods have been developed as diagnostic tools for a number of nematodes [39-42]. The ITS-2 region has been used as a molecular marker for diagnosis and epidemiological investigation [43-46]. Therefore, the characterization of the $\mathrm{mt}$ genome of $O$. trifurcata now provides the basis for the development of innovative analytical and diagnostic tools as well as novel genetic markers.

The $\mathrm{mt}$ genome sequences, particularly sequences of protein coding genes have been used effectively for the systematic examination of the nematodes [9,17,27,47-50]. Consequently, we ascertained the mt genome of O. trifurcata in the current study, allowing a reassessment of systematic relationships using the datasets of Trichostrongyloidea nematodes. Regarding the members of Trichostrongyloidea (Trichostrongylidea, Cooperiidae, Haemonchidae, Molineidae and Dictyocaulidae), there have been disagreements about their systematic taxonomy. To date, the mt genomes of a number of species belonging to Trichostrongyloidea are not represented or are underrepresented. Therefore, expansion of the taxa sampling is very important to carrying out phylogenetic studies of Trichostrongyloidea species utilizing the $\mathrm{mt}$ genome datasets in the future.

\section{Conclusions}

The complete mt genome of O. trifurcata was determined in the present study. The molecular data presented in this study provides new mtDNA resources for the better consideration of phylogeny and 
$\mathrm{mt}$ genomics. It also provides useful and unique genetic markers for studying the diagnosis, molecular epidemiology, systematics and population genetics of $O$. trifurcata in small ruminants.

Author Contributions: Conceptualization, M.H.; Methodology, A.A.A.; Software, not applicable; Validation, A.A.A., X.Y. (Xin Yang), M.H.; Formal Analysis, A.A.A., X.Y. (Xin Yang), Investigation, A.A.A., T.Z., C.W., C.Z., X.Y. (Xingrun Yan), M.H.; Resources, M.H.; Data Curation, A.A.A.; Writing-Original Draft Preparation, A.A.A.; Writing-Review \& Editing, A.A.A., X.Y. (Xin Yang), M.I., M.H.; Supervision, M.H.; Project Administration, M.H.; Funding Acquisition, M.H.

Funding: This research was funded by National Key Research and Development Program of China (2018YFD0501600) to M.H.

Conflicts of Interest: The authors declare no conflict of interest.

\section{References}

1. Gasser, R.B.; Bott, N.J.; Chilton, N.B.; Hunt, P.; Beveridge, I. Toward practical, DNA-based diagnostic methods for parasitic nematodes of livestock-Bionomic and biotechnological implications. Biotechnol. Adv. 2008, 26, 325-334. [CrossRef] [PubMed]

2. Ma, J.; He, S.W.; Li, H.; Guo, Q.C.; Pan, W.W.; Wang, X.J.; Zhang, J.; Liu, L.Z.; Liu, W.; Liu, Y. First survey of helminths in adult goats in Hunan Province, China. Trop. Biomed. 2014, 31, 261-269. [PubMed]

3. Blaxter, M.L.; De Ley, P.; Garey, J.R.; Llu, L.X.; Scheldeman, P.; Vierstraete, A.; Vanfleteren, J.R.; Mackey, L.Y.; Dorrls, M.; Frisse, L.M.; et al. A molecular evolutionary framework for the phylum Nematoda. Nature 1998, 392, 71-75. [CrossRef] [PubMed]

4. Blaxter, M.; Koutsovoulos, G. The evolution of parasitism in Nematoda. Parasitology 2015, 142, S26-S39. [CrossRef] [PubMed]

5. Waghorn, T.S.; Bouchet, C.L.G.; Bekelaar, K.; Leathwick, D.M. Nematode parasites in young cattle: What role for unexpected species? N. Z. Vet. J. 2019, 67, 40-45. [CrossRef] [PubMed]

6. Hoberg, E.P.; Lichtenfels, J.R. Phylogenetic systematic analysis of the Trichostrongylidae (Nematoda), with an initial assessment of coevolution and biogeography. J. Parasitol. 1994, 80, 976-996. [CrossRef] [PubMed]

7. Tariq, K.A. A Review of the Epidemiology and Control of Gastrointestinal Nematode Infections of Small Ruminants. Proc. Natl. Acad. Sci. India Sect. B Biol. Sci. 2015, 85, 693-703. [CrossRef]

8. Wall, R. Veterinary Parasitology, 4th ed.; Wiley: Hoboken, NJ, USA, 2016.

9. Sun, M.M.; Liu, G.H.; Ando, K.; Woo, H.C.; Ma, J.; Sohn, W.M.; Sugiyama, H.; Zhu, X.Q. Complete mitochondrial genomes of Gnathostoma nipponicum and Gnathostoma sp., and their comparison with other Gnathostoma species. Infect. Genet. Evol. 2017, 48, 109-115. [CrossRef]

10. Wolstenholme, D.R. Animal Mitochondrial DNA: Structure and Evolution. Int. Rev. Cytol. 1992, 141, $173-216$.

11. Boore, J.L. Animal mitochondrial genomes. Nucleic Acids Res. 1999, 27, 1767-1780. [CrossRef]

12. Liu, G.-H.; Lin, R.-Q.; Li, M.-W.; Liu, W.; Liu, Y.; Yuan, Z.-G.; Song, H.-Q.; Zhao, G.-H.; Zhang, K.-X.; Zhu, X.-Q. The complete mitochondrial genomes of three cestode species of Taenia infecting animals and humans. Mol. Biol. Rep. 2011, 38, 2249-2256. [CrossRef] [PubMed]

13. Song, F.; Li, H.; Shao, R.; Shi, A.; Bai, X.; Zheng, X.; Heiss, E.; Cai, W. Rearrangement of mitochondrial tRNA genes in flat bugs (Hemiptera: Aradidae). Sci. Rep. 2016, 6, 2-11. [CrossRef] [PubMed]

14. Song, N.; Cai, W.; Li, H. Deep-level phylogeny of Cicadomorpha inferred from mitochondrial genomes sequenced by NGS. Sci. Rep. 2017, 7, 1-11. [CrossRef] [PubMed]

15. Herd, K.E.; Barker, S.C.; Shao, R. The mitochondrial genome of the chimpanzee louse, Pediculus schaeffi: Insights into the process of mitochondrial genome fragmentation in the blood-sucking lice of great apes. BMC Genom. 2015, 16, 1-8. [CrossRef] [PubMed]

16. Li, H.; Leavengood, J.M.; Chapman, E.G.; Burkhardt, D.; Song, F.; Jiang, P.; Liu, J.; Zhou, X.; Cai, W. Mitochondrial phylogenomics of Hemiptera reveals adaptive innovations driving the diversification of true bugs. Proc. R. Soc. B Biol. Sci. 2017, 284, 20171223. [CrossRef] [PubMed]

17. Wang, B.J.; Gu, X.B.; Yang, G.Y.; Wang, T.; Lai, W.M.; Zhong, Z.J.; Liu, G.H. Mitochondrial genomes of Heterakis gallinae and Heterakis beramporia support that they belong to the infraorder Ascaridomorpha. Infect. Genet. Evol. 2016, 40, 228-235. [CrossRef] [PubMed] 
18. Gouÿ De Bellocq, J.; Ferté, H.; Depaquit, J.; Justine, J.L.; Tillier, A.; Durette-Desset, M.C. Phylogeny of the Trichostrongylina (Nematoda) inferred from 28S rDNA sequences. Mol. Phylogenet. Evol. 2001, 19, 430-442. [CrossRef]

19. Jex, A.R.; Hall, R.S.; Littlewood, D.T.J.; Gasser, R.B. An integrated pipeline for next-generation sequencing and annotation of mitochondrial genomes. Nucleic Acids Res. 2009, 38, 522-533. [CrossRef] [PubMed]

20. Durette-Desset, M.-C. Trichostrongyloid Nematodes and their Vertebrate Hosts: Reconstruction of the Phylogeny of a Parasitic Group. Adv. Parasitol. 1985, 24, 239-306. [PubMed]

21. Durette-Desset, M.C.; Chabaud, A.G. Strongylida Nomenclature for Taxa above the Family Group. Ann. Parasitol. Hum. Comp. 1993, 68, 111-112. [CrossRef]

22. Zhao, G.H.; Jia, Y.Q.; Cheng, W.Y.; Zhao, W.; Bian, Q.Q.; Liu, G.H. Characterization of the complete mitochondrial genomes of Nematodirus oiratianus and Nematodirus spathiger of small ruminants. Parasites Vectors 2014, 7, 1-9. [CrossRef] [PubMed]

23. Lin, R.Q.; Liu, G.H.; Hu, M.; Song, H.Q.; Wu, X.Y.; Li, M.W.; Zhang, Y.; Zou, F.C.; Zhu, X.Q. Oesophagostomum dentatum and Oesophagostomum quadrispinulatum: Characterization of the complete mitochondrial genome sequences of the two pig nodule worms. Exp. Parasitol. 2012, 131, 1-7. [CrossRef] [PubMed]

24. Anshary, H.; Sriwulan; Freeman, M.A.; Ogawa, K. Occurrence and molecular identification of Anisakis Dujardin, 1845 from marine fish in southern Makassar Strait, Indonesia. Korean J. Parasitol. 2014, 52, 9-19. [CrossRef]

25. Hu, M.; Chilton, N.B.; Gasser, R.B. Long PCR-based amplification of the entire mitochondrial genome from single parasitic nematodes. Mol. Cell. Probes 2002, 16, 261-267. [CrossRef] [PubMed]

26. Hu, M.; Jex, A.R.; Campbell, B.E.; Gasser, R.B. Long pcr amplification of the entire mitochondrial genome from individual helminths for direct sequencing. Nat. Protoc. 2007, 2, 2339-2344. [CrossRef] [PubMed]

27. Liu, G.H.; Jia, Y.Q.; Wang, Y.N.; Zhao, G.H.; Zhu, X.Q. The complete mitochondrial genome of the gullet worm gongylonema pulchrum: Gene content, arrangement, composition and phylogenetic implications. Parasites Vectors 2015, 8, 1-8. [CrossRef] [PubMed]

28. Guo, A. Complete mitochondrial genome of Anoplocephala magna solidifying the species. Korean J. Parasitol. 2016, 54, 369-373. [CrossRef]

29. Laslett, D.; Canbäck, B. ARWEN: A program to detect tRNA genes in metazoan mitochondrial nucleotide sequences. Bioinformatics 2008, 24, 172-175. [CrossRef]

30. Hu, M.; Chilton, N.B.; Gasser, R.B. The mitochondrial genomes of the human hookworms, Ancylostoma duodenale and Necator americanus (Nematoda: Secernentea). Int. J. Parasitol. 2002, 32, 145-158. [CrossRef]

31. Sun, M.M.; Han, L.; Zhang, F.K.; Zhou, D.H.; Wang, S.Q.; Ma, J.; Zhu, X.Q.; Liu, G.H. Characterization of the complete mitochondrial genome of Marshallagia marshalli and phylogenetic implications for the superfamily Trichostrongyloidea. Parasitol. Res. 2018, 117, 307-313. [CrossRef]

32. VAN DER VEER, M.; DE VRIES, E. A single nucleotide polymorphism map of the mitochondrial genome of the parasitic nematode Cooperia oncophora. Parasitology 2004, 128, 421-431. [CrossRef] [PubMed]

33. Jex, A.R.; Hu, M.; Littlewood, D.T.J.; Waeschenbach, A.; Gasser, R.B. Using 454 technology for long-PCR based sequencing of the complete mitochondrial genome from single Haemonchus contortus (Nematoda). BMC Genom. 2008, 9, 1-14. [CrossRef] [PubMed]

34. Gasser, R.B.; Jabbar, A.; Mohandas, N.; Höglund, J.; Hall, R.S.; Littlewood, D.T.J.; Jex, A.R. Assessment of the genetic relationship between Dictyocaulus species from Bos taurus and Cervus elaphus using complete mitochondrial genomic datasets. Parasites Vectors 2012, 5, 241. [CrossRef] [PubMed]

35. Katoh, K.; Standley, D.M. MAFFT multiple sequence alignment software version 7: Improvements in performance and usability. Mol. Biol. Evol. 2013, 30, 772-780. [CrossRef] [PubMed]

36. Liu, G.H.; Nadler, S.A.; Liu, S.S.; Podolska, M.; D’Amelio, S.; Shao, R.; Gasser, R.B.; Zhu, X.Q. Mitochondrial phylogenomics yields strongly supported hypotheses for ascaridomorph nematodes. Sci. Rep. 2016, 6, 1-8. [CrossRef] [PubMed]

37. Liu, G.H.; Wang, Y.; Xu, M.J.; Zhou, D.H.; Ye, Y.G.; Li, J.Y.; Song, H.Q.; Lin, R.Q.; Zhu, X.Q. Characterization of the complete mitochondrial genomes of two whipworms Trichuris ovis and Trichuris discolor (Nematoda: Trichuridae). Infect. Genet. Evol. 2012, 12, 1635-1641. [CrossRef] [PubMed]

38. Shadel, G.S.; Clayton, D.A. Mitochondrial DNA maintenance in vertebrates. Annu. Rev. Biochem. 1997, 66, 409-435. [CrossRef] 
39. Lodh, N.; Caro, R.; Sofer, S.; Scott, A.; Krolewiecki, A.; Shiff, C. Diagnosis of Strongyloides stercoralis: Detection of parasite-derived DNA in urine. Acta Trop. 2016, 163, 9-13. [CrossRef]

40. Fernández-Soto, P.; Sánchez-Hernández, A.; Gandasegui, J.; Bajo Santos, C.; López-Abán, J.; Saugar, J.M.; Rodríguez, E.; Vicente, B.; Muro, A. Strong-LAMP: A LAMP Assay for Strongyloides spp. Detection in Stool and Urine Samples. Towards the Diagnosis of Human Strongyloidiasis Starting from a Rodent Model. PLoS Negl. Trop. Dis. 2016, 10, e0004836. [CrossRef]

41. Solórzano-García, B.; Pérez-Ponce de León, G. Helminth parasites of howler and spider monkeys in Mexico: Insights into molecular diagnostic methods and their importance for zoonotic diseases and host conservation. Int. J. Parasitol. Parasites Wildl. 2017, 6, 76-84. [CrossRef]

42. Roeber, F.; Morrison, A.; Casaert, S.; Smith, L.; Claerebout, E.; Skuce, P. Multiplexed-tandem PCR for the specific diagnosis of gastrointestinal nematode infections in sheep: An European validation study. Parasites Vectors 2017, 10, 1-11. [CrossRef] [PubMed]

43. Gasser, R.B.; Chilton, N.B.; Hoste, H.; Beveridge, I. Rapid sequencing of rDNA from single worms and eggs of parasitic helminths. Nucleic Acids Res. 1993, 21, 2525-2526. [CrossRef] [PubMed]

44. Lee, Y.; Choi, Y.; Min, B. PCR-RFLP and sequence analysis of the rDNA ITS region in the Fusarium spp. J. Microbiol. 2000, 38, 66-73.

45. Lotfy, W.M.; Brant, S.V.; Ashmawy, K.I.; Devkota, R.; Mkoji, G.M.; Loker, E.S. A molecular approach for identification of paramphistomes from Africa and Asia. Vet. Parasitol. 2010, 174, 234-240. [CrossRef] [PubMed]

46. Nguyen, T.D.; Le, Q.D.; Huynh, V.V.; Nguyen, S.T.; Nguyen, T.V.; Vu-Khac, H. The development of PCR methodology for the identification of species of the tapeworm Moniezia from cattle, goats and sheep in central Vietnam. J. Helminthol. 2012, 86, 426-429. [CrossRef] [PubMed]

47. Kim, J.; Kern, E.; Kim, T.; Sim, M.; Kim, J.; Kim, Y.; Park, C.; Nadler, S.A.; Park, J.K. Phylogenetic analysis of two Plectus mitochondrial genomes (Nematoda: Plectida) supports a sister group relationship between Plectida and Rhabditida within Chromadorea. Mol. Phylogenet. Evol. 2017, 107, 90-102. [CrossRef] [PubMed]

48. Aghazadeh, M.; Traub, R.J.; Mohandas, N.; Aland, K.V.; Reid, S.A.; McCarthy, J.S.; Jones, M.K. The mitochondrial genome of Angiostrongylus mackerrasae as a basis for molecular, epidemiological and population genetic studies. Parasites Vectors 2015, 8, 1-11. [CrossRef] [PubMed]

49. Blouin, M.S. Molecular prospecting for cryptic species of nematodes: Mitochondrial DNA versus internal transcribed spacer. Int. J. Parasitol. 2002, 32, 527-531. [CrossRef]

50. Sun, M.M.; Ma, J.; Sugiyama, H.; Ando, K.; Li, W.W.; Xu, Q.M.; Liu, G.H.; Zhu, X.Q. The complete mitochondrial genomes of Gnathostoma doloresi from China and Japan. Parasitol. Res. 2016, 115, 4013-4020. [CrossRef]

(C) 2019 by the authors. Licensee MDPI, Basel, Switzerland. This article is an open access article distributed under the terms and conditions of the Creative Commons Attribution (CC BY) license (http://creativecommons.org/licenses/by/4.0/). 